\title{
INVESTIGATION OF THE MECHANICAL PROPERTIES OF ELECTROCHEMICALLY DEPOSITED Au-In ALLOY FILMS USING NANO-INDENTATION
}

\author{
PREISKAVA MEHANSKIH LASTNOSTI ELEKTROKEMIJSKO \\ NANEŠENEGA FILMA ZLITINE Au-In Z NANOVTISKOVANJEM
}

\author{
Sabina Cherneva ${ }^{1}$, Roumen Iankov¹, Martin Georgiev², Tsvetina Dobrovolska ${ }^{2}$, \\ Dimitar Stoychev ${ }^{2}$
}

${ }^{1}$ Bulgarian Academy of Sciences, Institute of Mechanics, Acad. G. Bonchev str., B1. 4, 1113 Sofia, Bulgaria ${ }^{2}$ Bulgarian Academy of Sciences, Institute of Physical Chemistry, Acad. G. Bonchev str., B1. 11, 1113 Sofia, Bulgaria sabina_cherneva@yahoo.com

Prejem rokopisa - received: 2015-06-26; sprejem za objavo - accepted for publication: 2015-09-09

doi:10.17222/mit.2015.129

\begin{abstract}
Thin Au-In alloy films containing different amounts of In were electrochemically deposited on a CuZn substrate with a 500- $\mu$ m thickness. The thicknesses of the obtained films varied from $0.4 \mu \mathrm{m}$ to $2.7 \mu \mathrm{m}$. The chemical and phase compositions, as well as the structures of the films, were investigated by XRF, XRD and SEM analysis. The mechanical properties of the films and substrates were investigated using nano-indentation experiments. As a result, load-displacement curves were obtained and two mechanical characteristics of the substrate and investigated films - indentation hardness and indentation modulus - were calculated using the Oliver \& Pharr approximation method. The dependence of the indentation modulus and the indentation hardness on the depth of the indentation and the content of In, the structure and the phase compositions of the films were investigated and discussed as well.

Keywords: gold-indium alloy, electrochemical deposition, mechanical properties, nano-indentation
\end{abstract}

Tanke plasti zlitine Au-In, z različno vsebnostjo In, so bile elektrokemijsko nanešene na podlago iz CuZn, debeline $500 \mu$ m. Debeline dobljene plasti so bile od $0,4 \mu \mathrm{m}$ to $2,7 \mu \mathrm{m}$. Kemijska sestava in sestava faz, kot tudi mikrostruktura plasti, so bile preiskovane z XRF, XRD in s SEM analizami. Mehanske lastnosti preiskovanih plasti so bile preiskane s pomočjo preizkusa z nanovtiskovanjem. Kot rezultat so bile dobljene krivulje obremenitev-raztezek. Dve mehanski lastnosti podlage in preiskovanih plasti - trdota vtiskovanja in modul vtiskovanja - sta bili izračunani s pomočjo Oliver \& Pharr metode približka. Preiskovana in prediskutirana je bila odvisnost modula vtiskovanja in trdota vtiskovanja na globino vtiska od vsebnosti In.

Ključne besede: zlitina zlato-indij, elektrokemijsko nanašanje, mehanske lastnosti, nanovtiskovanje

\section{INTRODUCTION}

The phase diagram of the gold-indium ${ }^{1}$ system shows the presence of several intermetallic compounds existing at a temperature lower than the melting point of Indium $\left(\sim 156^{\circ} \mathrm{C}\right)$, including stable AuIn and $\mathrm{AuIn}_{2}$ phases with a cubic lattice, similar to the $\alpha$-phase of gold. The indium phase starting from a $53 \%$ mass fraction is tetragonal. The average microhardness obtained for the metallurgical alloy system $\mathrm{Au}-\mathrm{In}$ is as follows: $\mathrm{Au}$ $(99.999 \%)=0.660, \alpha$ AuIn $(8 \%$ of amount fractions of In $)=1.700, \zeta_{1}$-phase $=3.68, \operatorname{AuIn}=2.73, \mathrm{AuIn}_{2}=0.77$ $\mathrm{GPa}$ and the alloy with $80 \%$ of amount fractions of In $=2.07 \mathrm{GPa}^{2}$ The microhardness in the hardened condition of the compound $\mathrm{Au}_{3} \mathrm{In}_{2}(\psi$ phase) is $1.83 \mathrm{GPa}$, and increases in the uniformity of the phase deviations in the stoichiometric composition. ${ }^{3}$ In contrast to metallurgically obtained, the electrochemically deposited Au-In alloys are not well studied. At the same time, electrochemically deposited thin layers of $\mathrm{Au}-\mathrm{In}$ alloys will find wide application (instead of pure gold coatings) in electrical engineering, micro-electronics, the manufacturing of various sensors, the jewelery industry, etc. The interest in studying the impact of the content of In in the $\mathrm{Au}-\mathrm{In}$ alloy on a number of colors, decorative, optical, corrosion, mechanical and other properties, regardless of the method of their production, has also increased. ${ }^{4-6}$ The aim of the present work is to investigate the indentation hardness and the indentation modulus of electrochemically deposited thin layers of Au-In alloys as a function of the indentation depth and considering the effect on them of the nature of the substrate, the content of In, the structure and phase composition of the alloy films as well as the surface roughness of the films.

\section{EXPERIMENTAL PART}

The Au-In alloy films with thicknesses between $0.4 \mu \mathrm{m}$ and $2.7 \mu \mathrm{m}$ were deposited onto brass sheet substrates $(2 \mathrm{~cm} \times 1 \mathrm{~cm} \times 0.03 \mathrm{~cm})$ in a standard electrochemical glass cell equipped with two Pt anodes as the counter electrodes. The standard preliminary treatment of the brass cathode-substrates includes a procedure for electrochemical decreasing, followed by pickling in a $20 \%$ water solution of sulphuric acid at room temperature. The investigated Au-In alloy films were electrodeposited 
in galvanostatic mode (in the range of cathodic current densities from 0.2 to $1.8 \mathrm{~A} \mathrm{dm}^{-2}$ ) of an acetate-citrate electrolyte (containing $1 \mathrm{~g} / \mathrm{L} \mathrm{Au}$ as a metal $\left(\mathrm{KAu}(\mathrm{CN})_{2}\right)$; $3 \mathrm{~g} / \mathrm{L} \mathrm{In}$ as a metal $\left(\mathrm{InCl}_{3}\right) ; 90 \mathrm{~g} / \mathrm{L} \mathrm{CH}_{3} \mathrm{COONa} ; 14 \mathrm{~g} / \mathrm{L}$ citric acid). The electrolysis process was performed without any stirring of the electrolyte and at room temperature. The thickness, content of In and percentage composition (Au:In) of the thin alloy films were determined by X-ray fluorescence analysis (Fischerscope XDAL). The structure and morphology of the layer surface were investigated by scanning electron microscopy (SEM) using a JSM 6390 microscope. The phase composition was characterized by X-ray diffraction (XRD) using a PANalytical Empyrean Equipped with a multichannel detector (Pixel 3D) using $\mathrm{Cu}-K_{\alpha}(45 \mathrm{kV}-40 \mathrm{~mA})$ radiation in the $20-115^{\circ} 2 \theta$ range with a scan step of $0.01^{\circ}$ per $20 \mathrm{~s}$. The mechanical properties of the Au-In alloy films containing different amounts of In onto the CuZn substrate were investigated by means of nano-indentation experiments, using a Nano Indenter G200 (Keysight Technologies, USA), equipped with a Berkovich three-sided diamond pyramid with a centerlineto-face angle of $65.3^{\circ}$ and a $20-\mathrm{nm}$ radius at the tip of the indenter. We realized a series of 25 indentations on each sample probe. We used an indentation method that was proposed in ${ }^{7}$. The indentation hardness and indentation modulus are determined using the stiffness calculated from the slope of the load-displacement curve during each unloading cycle. As a result load-displacement curves were obtained and two mechanical characteristics of the substrate and the investigated films - indentation hardness $\left(H_{\mathrm{IT}}\right)$ and indentation modulus $\left(E_{\mathrm{IT}}\right)$ - were calculated using the Oliver \& Pharr approximation method. ${ }^{8}$

\section{RESULTS AND DISCUSSION}

Table 1 shows the results of the XRF analyses on the chemical composition, thickness $(\delta)$ and the micro roughness $\left(R_{\mathrm{z}}\right.$ and $\left.R_{\mathrm{a}}\right)$ of the tested alloy samples and the brass substrate on which they were deposited. From the results it can be seen that the interval of changes in content $49-63 \%$ for the mass fractions of indium in the resulting thin alloy layers and changes of their micro roughness. Information about the surface morphology
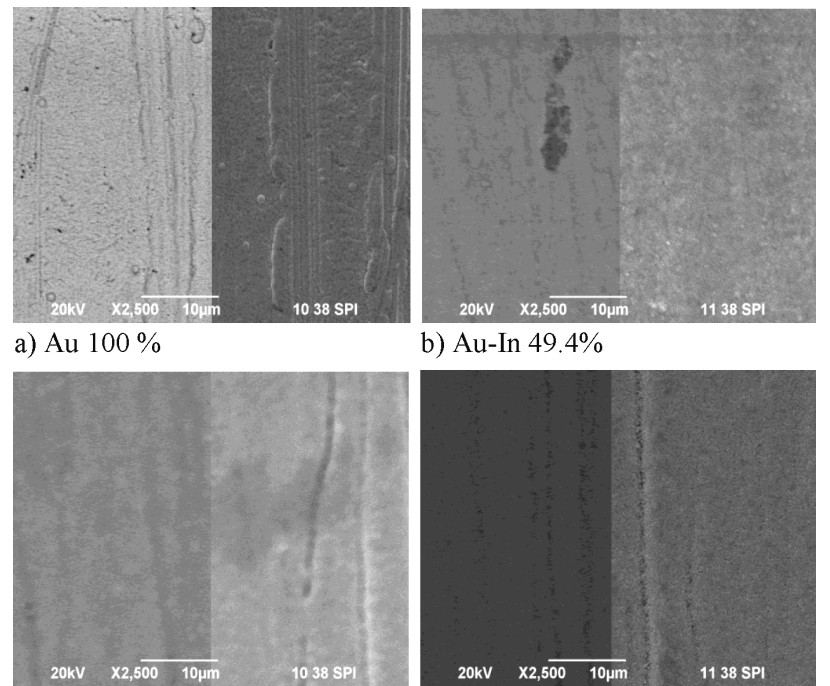

b) $\mathrm{Au}-\mathrm{In} 49.4 \%$

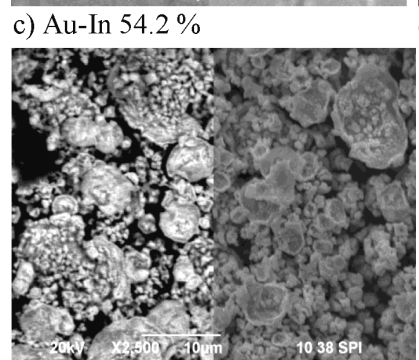

e) $\mathrm{Au}-\mathrm{In} 63 \%$

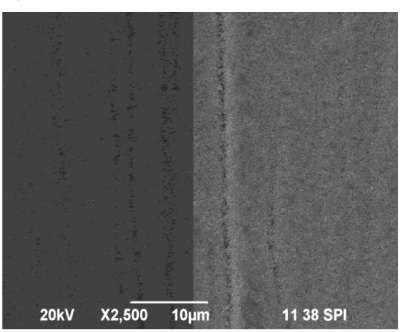
d) Au-In $56 \%$

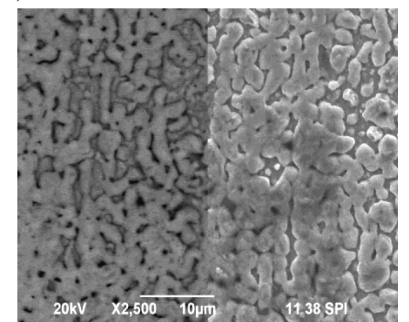

f) In $100 \%$

Figure 1: SEM microphotographs of deposited a) Au $100 \%$ : f) In 100 $\%$ and $\mathrm{Au}-\mathrm{In}$ alloy layers in which the content of indium (in mass fractions, (w/\%) is: b) $49.4 \% \mathrm{In}$, c) $54.2 \% \mathrm{In}$, d) $56.0 \%$ In and e) 63 $\%$ In (samples No. 2, 7, 3, 4, 5, 6 described in Table 1)

Slika 1: SEM-posnetek nanosa: a) Au $100 \%$, f) In $100 \%$ in nanosi AuIn z različno vsebnostjo In (v masnih odstotkih, (w/\%): b) 49,4\% In, c) $54,2 \%$ In, d) 56,0\% In, e) $63 \%$ In (vzorci št. 2, 7, 3, 4, 5, 6 opisani v Tabeli 1)

and the structure of the electrodeposited pure Au and In coatings of the working electrolyte for the preparation of the alloy coatings of which in the first case the presence of In ions is excluded, and in the second case, the presence of $\mathrm{Au}$ ions is excluded, give the microphotographs presented in Figure 1a and 1f. While the $\mathrm{Au}$ coating is dense and uniform, formed by spherical crystallites having a size $\sim 0.5-1.2 \mu \mathrm{m}$ (Figure 1a), the coatings of In have an uneven thickness - over the fine crystal thin indium layer which covers the entire surface

Table 1: Chemical composition, thickness, $R_{z}$ and $R_{\mathrm{a}}$ of the investigated Au-In alloy layers and the substrate on which they are deposited Tabela 1: Kemijska sestava, debelina, $R_{z}$ in $R_{\mathrm{a}}$ preiskovanih AuIn plasti in podlage, na katero so bile nanešene

\begin{tabular}{|c|l|l|c|c|c|c|}
\hline No & \multicolumn{1}{|c|}{ Sample } & $\begin{array}{c}\text { Content in mass fractions, } \\
(w / \%)\end{array}$ & $\delta, \mu \mathrm{m}$ & $R_{\mathrm{a}}, \mu \mathrm{m}$ & $R_{z}, \mu \mathrm{m}$ & $\mathrm{J}, \mathrm{A}$ dm ${ }^{2}$ deposition time, min \\
\hline 1. & Brass substrate (pickled) & $\mathrm{Cu}-65.80 ; \mathrm{Zn}-34.20$ & 300 & 1.61 & 9.13 & \\
\hline 2. & $\mathrm{Au} /$ Brass & $\mathrm{Au}-100$ & 0.64 & 1.13 & 4.77 & \\
\hline 3. & AuIn/Brass & $\mathrm{Au}-50.6 ; \mathrm{In}-49.4$ & 0.56 & 1.14 & 4.90 & $1.0 ; 20$ \\
\hline 4. & AuIn/Brass & $\mathrm{Au}-45.8 ; \mathrm{In}-54.2$ & 0.75 & 1.40 & 5.37 & $1.8 ; 7$ \\
\hline 5. & AuIn/Brass & $\mathrm{Au}-44.1 ; \mathrm{In}-56.0$ & 1.42 & 1.15 & 5.00 & $1.2 ; 15$ \\
\hline 6. & AuIn/Brass & $\mathrm{Au}-37.0 ; \mathrm{In}-63.0$ & 2.76 & 1.50 & 8.93 & $0.6 ; 20$ \\
\hline 7. & In/Brass & $\mathrm{In}-100$ & 0.49 & 1.18 & 3.83 & \\
\hline
\end{tabular}




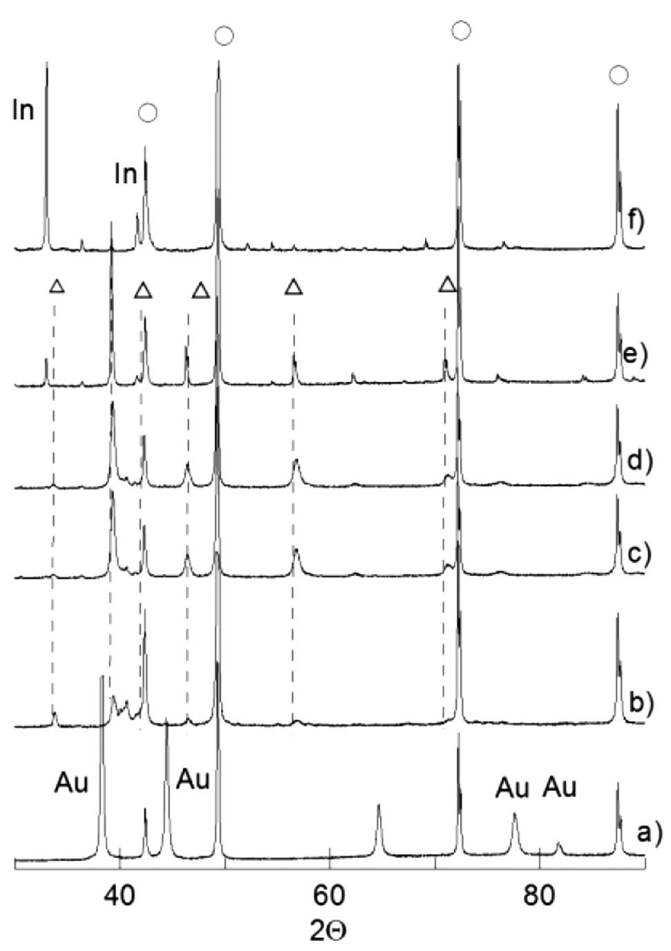

Figure 2: XRD patterns of the: a) $\mathrm{Au} 100 \%, \mathrm{f})$ In $100 \%$ and $\mathrm{Au}-\mathrm{In}$ alloy layers, containing: b) $49.4 \% \mathrm{In}$, c) $54.2 \% \mathrm{In}$, d) $56.0 \% \mathrm{In}$, e) $63 \% \mathrm{In} ;(\mathrm{o})$ - reflections of CuZn substrates, $(\Delta)$ - reflections of $\mathrm{AuIn}_{2}$

Slika 2: Rentgenogram: a) Au $100 \%$, f) In $100 \%$ in AuIn nanosa z: b) $49,4 \%$ In, c) $54,2 \%$ In, d) $56,0 \%$ In, e) $63 \%$ In; (o) odboji CuZn podlage, $(\Delta)$ odboji AuIn,

of the brass substrate, they grew, not fully coalesced, spheroidal agglomerates with size $\sim 1-10 \mu \mathrm{m}$ (Figure 1f). The influence of changes in the content of indium on the surface morphology and structure of the Au-In alloy layers is presented in Figures $\mathbf{1 b}$ to 1e. From the microphotographs it is clear that at the lowest content of indium (49.4\%) (Figure 1b) the film has a morphology and structure that is different from that of the pure gold film. The alloy coating is formed by homogeneously distributed agglomerates of a size of the base several times

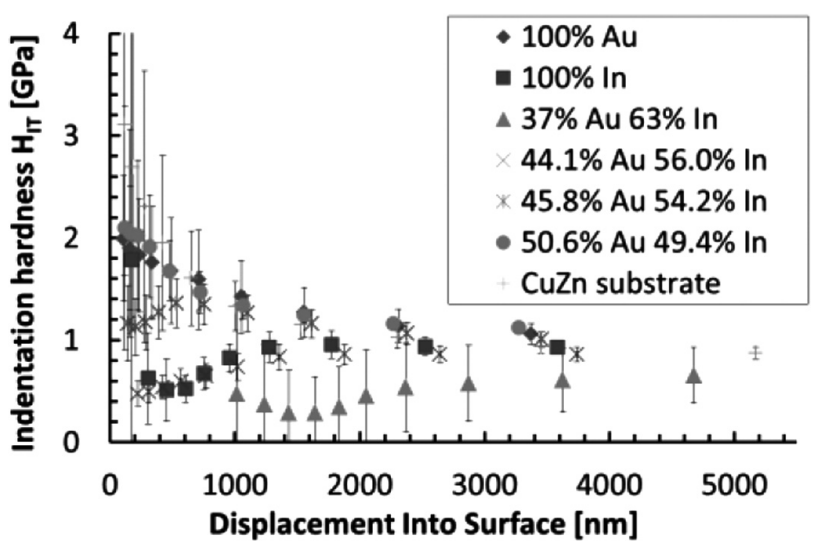

Figure 3: Dependence of the indentation hardness on the depth of the indentation

Slika 3: Odvisnost trdote vtiskovanja od globine vtiskovanja

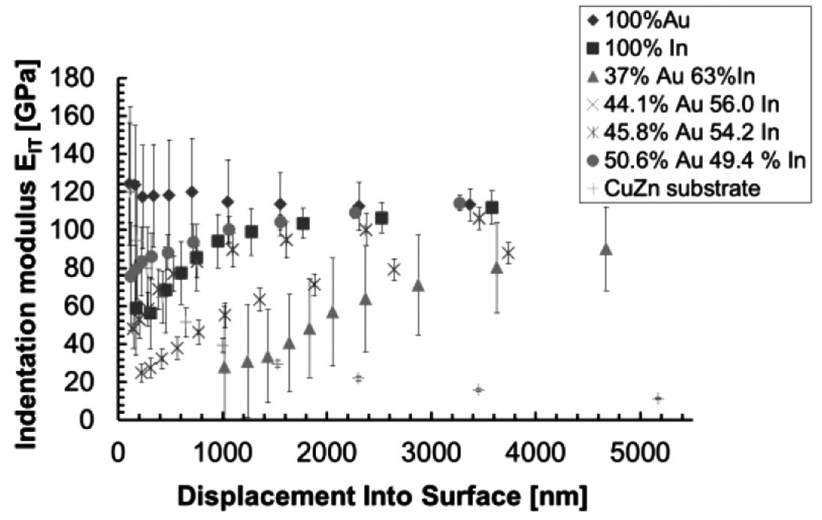

Figure 4: Dependence of indentation modulus on the depth of the indentation

Slika 4: Odvisnost modula vtiskovanja od globine vtiskovanja

larger than that of the spherical grains constituting the gold coating. Moreover, there was no phase heterogeneity in the regime of back scattering electrons. The reasons for this conclusion give the images on the lefthand side of the SPI electron microscopic image (Figure 1b), obtained in the regime of back scattering electrons (BEI), while the right-hand part of the photograph shows an image that was obtained in the regime of a secondary-electron image (SEI). With the same purpose (the recording of possible phase heterogeneity) are the SPI electron microscopic images for a higher content of In (Figures 1c to 1e). Increasing the content of indium in the alloy layer to $\sim 54 \%$ (Figure 1c), leads to a levelling of the morphology, respectively, to a finer structure compared with those at a content of $\sim 49 \%$ (Figure 1b), in which an even greater degree was observed in the next amount $(\sim 56 \%)$ of indium (Figure 1d). Obviously, the observed differences in morphology are not related to the phase, but are related to the topographic heterogeneity. When the content of co-deposited In, however, reached $63 \%$, the morphology and the structure drastically change; they are characterized by large aggregates $(3-15 \mu \mathrm{m})$, composed of crystallites with dimensions of $0.5-1 \mu \mathrm{m}$. Moreover, the BEI image (left-hand side) of the electron microscopic micrograph, at this content (Figure 1e)

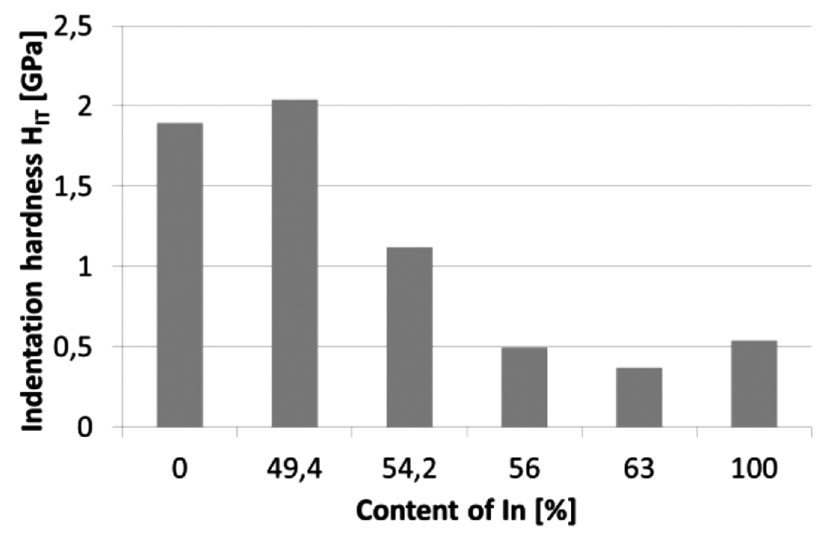

Figure 5: Dependence of the indentation hardness on the content of In Slika 5: Odvisnost trdote vtiskovanja od vsebnosti In 


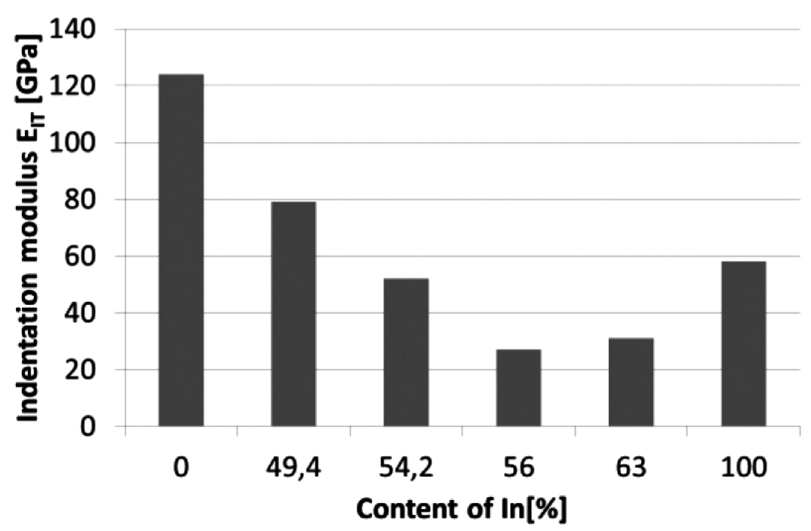

Figure 6: Dependence of the indentation modulus on the content of In Slika 6: Odvisnost modula vtiskovanja od vsebnosti In

indicates the occurrence of phase heterogeneity. The $\mathrm{X}$-ray phase analysis of the same alloy samples (Figure 2) showed that for electrodeposited samples of electrolyte containing only gold ions (in the absence of indium ions) the diffractogram showed the presence of reflections of the cubic lattice $(a=b=c=4.08)$ of the phase of gold (pdf 98-004-4362), and reflections of the brass substrate (pdf 98-062-9457) (Figure 2a). In the case of the electrodeposition of an indium film (in the absence of gold ions in the electrolyte), the diffractogram of the obtained sample indicates the presence of reflections of an In tetragonal phase (pdf 98 005-3091) with the lattice parameters $a=0.3253 \mathrm{~nm}, b=0.49455 \mathrm{~nm}$ and reflections of the substrate made of brass (pdf 98-062-9457) (Figure 2f). Since the content of indium in the electrodeposited alloy film is in the range 49-63\% of mass fractions of In, then, according to the phase diagram for the system $\mathrm{Au}-\mathrm{In}$, they fall into the area of the phase $\mathrm{AuIn}_{2}$. This is confirmed by the recorded reflections in the diffractograms presented in Figures $\mathbf{2 b}$ to $\mathbf{2 e}$. The $\mathrm{AuIn}_{2}$ phase has a cubic lattice with highly expanded parameters regarding the $\alpha$-phase of the gold ( $a=b=c=$ 6.502). Only in the alloy composition containing over 63 $\%$ of mass fractions of In (Figure 2e) is there a presence of both the phase $\mathrm{AuIn}_{2}$ and the tetragonal phase of In (pdf 98005-3091), which is the most likely cause for registered, strongly emphasized, morphological heterogeneity of the alloy coating (Figure 1). The dependence of the indentation hardness and the indentation modulus of the investigated alloy films on the depth of the indentation are shown in Figures 3 and 4. With an increasing depth of indentation, the indentation hardness and the modulus change a great deal. There are two possible reasons for this: the influence of the substrate and the effect of the difference in the structure with depth. The dependence of the indentation hardness and the indentation modulus of the investigated alloy films (at load $=$ $1.15 \mathrm{mN}$, in order to be far enough from the influence of the substrate) on the content of In is shown in Figures 5 and 6. With an increase of the content of In from 0 to $49.4 \%$, the indentation hardness increases too, and after this (from $54.2 \%$ to $63 \%$ content of In) it starts to decrease. It is obvious from Figure 6 that with an increase in the In content up to $56.0 \%$ and $63 \%$ the indentation modulus of the investigated Au-In films decreases. This could be explained by the influence of the simultaneously existing two phases on the surface electrode: In and $\mathrm{AuIn}_{2}$. The effect of the non-regularity is very strong due to the different type of crystal lattice tetragonal in case of the In phase and cubic in the case of the $\mathrm{AuIn}_{2}$ phase. Most probably, the inhomogeneity of these two phases, as well as their roughness limit the accuracy, due to the randomly of both phases during the performed measurements.

\section{CONCLUSIONS}

In the present work the mechanical properties of electrochemically deposited thin layers of $\mathrm{Au}-\mathrm{In}$ alloys as a function of the indentation depth and considering the effect on them of the nature of the substrate, the content of In, the structure and the phase composition of the alloy films as well as the surface roughness of the films were investigated. The results showed that with an increasing content of In from $0 \%$ to $49.4 \%$, the indentation hardness increased too and after this (from $54.2 \%$ to $63 \%$ content of In) it starts to decrease. Moreover, with an increase in the In content up to $56.0 \%$ and $63 \%$ the indentation modulus of the investigated Au-In films decreases. This could be explained by the influence of the simultaneously existing two phases on the surface electrode: In and $\mathrm{AuIn}_{2}$. The effect of the non-regularity is very strong due to the different types of crystal lattice: tetragonal in the case of the In phase and cubic in the case of the $\mathrm{AuIn}_{2}$ phase.

\section{Acknowledgments}

Authors gratefully acknowledge the financial support of Bulgarian National Science Fund under Grant No. T02-22/12.12.2014.

\section{REFERENCES}

${ }^{1}$ T. Massalski, J. Murray, B. Lawrence, B. Hugh, Binary Alloy Phase Diagram, American Society for Metals, Metals Park, Ohio, 1 (1986) 90, 260-270

${ }^{2}$ G. W. Powell, J. D. Braun, Diffusion in the gold-indium system, Transactions of the Metallurgical Society of AIME, 230 (1964) 4, 694-699

${ }^{3}$ V. K. Nikitina, A. A. Babitsina, U. K. Lobanova, Phase diagrams of the system Au-In, Inorganic materials (in russian), Izvestia AN SSSR, 7 (1971) 3, 421-427

${ }^{4}$ L. C. Archibald, G. Sanderson, Electrodeposition of a White Gold-Indium Alloy from an Acid Cyanide Electrolyte, Transactions of the Institute of Metal Finishing, 55 (1978) 4, 149-154

${ }^{5}$ C. Cretu, E. Van der Lingen, Coloured Gold Alloys, Gold Bulletin, 32 (1999) 4, 115-126, doi: 10.1007/BF03214796 


\section{S. CHERNEVA et al.: INVESTIGATION OF THE MECHANICAL PROPERTIES OF ELECTROCHEMICALLY DEPOSITED ...}

${ }^{6}$ U. E. Klotz, Metallurgy and processing of coloured gold intermetallics - Part I: Properties and surface processing, Gold Bulletin, 43 (2010) 1, 4-10, doi: 10.1007/BF03214961

M. Datcheva, S. Cherneva, D. Stoychev, R. Iankov, M. Stoycheva, Determination of Anodized Aluminum Material Characteristics by Means of Nanoindentation Measurements, Materials Sciences and Applications, 2 (2011) 10, 1452-1464, doi:10.4236/msa.2011. 210196

${ }^{8}$ W. Oliver, G. Pharr, Measurement of hardness and elastic modulus by instrumented indentation: Advances in understanding and refinements to methodology, Journal of Materials Research, 19 (2004) 1, 3-20 